\title{
TAKING THE BUNDLE OF RIGHTS SERIOUSLY
}

\author{
Jesse Wall*
}

After a painfully long set up, that attempts to ground three claims about property law (in general) and the nature of the beneficial interest (in particular), this article considers two arguments about the law of discretionary trusts. The first is the bundle of rights argument. This argument concerns the interpretation of "property" in legislative provisions. It suggests that where legislation is concerned with the structure of the social relationships that property institutions facilitate (rather that the juridical structure of rights and duties under property law), interpretations regarding what amounts to a "property" interest should also be "functional" (rather than "formalistic"). The second argument is the concept of the illusory trust. This argument concerns the standard package of constitutive elements required by trust law when a settlor uses the trust institution to order his or her affairs. Where an ostensible trust lacks a constitutive element, it can be said to be illusory. I consider here recent attempts to further delineate the concept of the illusory trust, that look to the "substance" or "reality" of the trust, and in doing so, shift our attention away from juridical form and onto social function. I will argue that only the former argument needs to be taken seriously.

According to the Law Commission's Review of the Law of Trusts, "[n]o coherent basis for the bundle of rights has been articulated to date, so it is difficult to predict what course the courts will take in the future". ${ }^{1}$ This article aims to provide a coherent basis for the bundle of rights theory of trust property. To do so, this article needs to articulate three preliminary claims. The first claim is that both a property right, and the beneficial interest under a trust, can be understood in terms of their juridical form of rights and duties or their functional structure of social relationships. The second is that we should understand the moral ends of property law, and the moral ends of the law of trusts, as either serving one underlying value or serving a plurality of values. The third claim is that, in order to advance the view that property law or trust law serves a plurality of values, it is necessary to adopt the functional view of property. Against this backdrop, this article will consider two arguments: the

Faculty of Law, University of Auckland. My thanks to James Penner and the participants at the New Zealand Centre for Legal Theory Colloquium for their comments on an earlier version of this paper.

1 Law Commission Some Issues With the Use of Trusts in New Zealand: Review of the Law of Trusts - Second Issues Paper (NZLC IP20, 2010) at 46-47. 
bundle of rights theory and the concept of the illusory trust. Whilst the "bundle of rights theory" is a coherent argument concerning the interpretation of "property" in legislative provisions, no coherent basis for the concept of the illusory trust has been articulated to date.

This article is structured like a Punnett square. Part I(A) is concerned with the form, function and moral ends - of property. Part I(B) is concerned with the form, function - and moral ends - of the beneficial interest. Part II(A) constructs an argument (the bundle of rights) that depends on a functional interpretation of "property" in light of a plurality of moral ends that property law might serve. Part II(B) then considers an argument (the concept of the illusory trust) that depends on a functional interpretation of the beneficial interest in the light of a plurality of moral ends that trust law might serve.

\section{PART ONE}

\section{A Property}

The purpose of this Part is to isolate "the bundle of rights theory" in the context of property law theory in general. This provides a prelude to articulating the basis of the bundle of rights theory in trust law (at Part II(A)) as well as introducing the two distinctions relied upon in the analysis of both the beneficial interest (at Part I(B)) and the limits of the concept of the trust (at Part II(B)). Specifically, this Part will distinguish between a "formal" and "functional" explanation of property law, and between a "monistic" and "pluralistic" explanation of the moral ends of property law. It will then connect the functional explanation of property with the debate on the moral ends of property law. These three manoeuvres - differentiating form and function, identifying different valuable ends, and connecting function with value - are overemphasised in this Part, as they provide the analytical structure for the remainder of this article.

But first, we need some tools with which to tackle the apparent competition between the explanations. So, allow me to start by introducing some technical language about explanations. An explanation has two parts. An explanation has an explanandum: a "sentence describing the phenomenon to be explained", 2 and an explanans: a class of sentences which can "account for the phenomenon". ${ }^{3}$ When we consider competing theoretical explanations of a phenomenon we need to consider whether the explanations have the same explanandum. Sometimes distinct explananda masquerade as competing explananda when the "sentence describing the phenomenon to be explained" is not articulated well. For example, if you walked into the kitchen and asked me "why is there smoke?" you have identified an explanandum (the phenomenon of smoke) and asked for an explanans (an account of the phenomenon of smoke). I might then respond to the question with an

2 Carl G Hempel and Paul Oppenheim "Studies in the Logic of Explanation" (1948) 15 Philosophy of Science 135 at 137 .

3 At 137. 
explanans: "because something is on fire". Despite my explanans providing the most accurate account of phenomena to be explained, you would be frustrated with my response. Your frustration stems from my narrow interpretation of the way you articulated the explanandum. To better articulate the explanandum, what you should have asked is "what is on fire?" since that is, most likely, the explanation that you sought when you walked into the kitchen. The two questions - why is there smoke? and what is on fire? - represent different explananda (smoke; fire) that call for different explanans. The implication here is that, unless the explanandum is properly articulated, we can mistake different explanans for competing explanans.

In the light of this, let us turn to consider theoretical explanations of property. On one theoretical account of property rights, "the differentiating feature of a system of property" is "the [moral] right of the owner to act as the exclusive gatekeeper of the owned thing". ${ }^{4}$ A property right is, on this account, the right to exclude all others from an object, asset or resource. This is the "right to exclude theory" of property. On another theoretical account, property rights represent "an open-ended set" of "activities" or "privileges", that include the ability to possess, consume, derive income from, control, manage, transfer, exchange, sell, borrow against, or otherwise use, the object, asset or resource. ${ }^{5}$ This is the "bundle of rights theory". Property, it would seem, represents either the right to exclude or a bundle of rights. As I will explain here, both accounts are accurate explanans of different explananda. They explain a different set of phenomena that we can identify in the exercise of property rights.

The exclusionary account of property rights, that takes the right to exclude all others from the object, asset or resource as the defining feature of a property right, is an account of the juridical form of property rights. Property rights exhibit a particular legal structure; property rights are enforceable against an open set of persons (are rights in rem), are actionable per se and impose correlative duties of non-interference. ${ }^{6}$ The "right to exclude" becomes shorthand for this legal structure that is organised around the idea that the rights-holder has the moral right to exclude all others from the object, asset or resource. The moral right to exclude is able to account for - or explain - this legal

4 Thomas W Merrill and Henry E Smith "The Morality of Property" (2007) 48 Wm \& Mary L Rev 1849 at 1850 .

5 Tony Honoré "Ownership" in Making Law Bind: Essays Legal and Philosophical (Clarendon Press, Oxford, 1987) 161; Roscoe Pound "The Law of Property and Recent Juristic Thought" (1939) 25 ABAJ 993 at 997; and Wesley Newcomb Hohfeld "Fundamental Legal Conceptions as Applied in Judicial Reasoning" (1917) 26 Yale LJ 710 at 746-747.

6 JE Penner The Idea of Property in Law (Clarendon Press, Oxford, 1997) at 128; Ben McFarlane The Structure of Property Law (Hart Publishing, Oxford, 2008) at 20-22; and Sarah Green "Rights and Wrongs: An Introduction to the Wrongful Interference Actions" in Donal Nolan and Andrew Robertson (eds) Rights and Private Law (Hart Publishing, Oxford, 2012) 525 at 536. 
form. ${ }^{7}$ Hence, for Thomas Merrill, it is "necessary to posit independently" the right to exclude as the differentiating feature of a system of property in order to account for the legal form of property rights. ${ }^{8}$ The juridical form or structure of property rights is the explanandum that the exclusionary theory of property is able to explain.

Whilst the exclusionary theory of property can explain the legal form or structure of the law, the bundle theory of property can account for the privileges and entitlements (the "incidents of ownership" or the "bundle of rights") that "sit behind" the form and structure of property rights. ${ }^{9}$ That is, it can explain how property law functions to enable the exercise of an open-ended set of privileges and entitlements in an object or resource. Property rights, therefore, protect an open-ended set of uses implicitly by giving the owner the right to exclude others from the asset, ${ }^{10}$ and the various privileges and entitlements in an object or resource "are mere elaborations of what the right to exclude encompasses or entails". ${ }^{11}$ By enabling the rights-holder to exclude all others from an object, asset or resource, the right to exclude "indirectly serves a wide - and, crucially, only vaguely specified - set of interests". ${ }^{12}$ The right to exclude others from an asset or resource renders "a protected sphere of indefinite and undefined activity, in which an owner may do anything with the things he owns". ${ }^{13}$ Within the formally "indefinite and undefined" sphere of activity, the law functions to protect a rather full bundle of rights.

We, therefore, arrive at different explanans of different explananda. Where the phenomena that calls for explanation is the juridical relationship between right-holders and duty-bearers, then the alienable right to exclude provides a sound explanation of the phenomenon. Where the phenomenon that calls for explanation is how property rights facilitate the relationship between people and resources, then the bundle of rights view provides a sound explanation of the phenomenona. Rather than being competing accounts of property rights, the right to exclude and the bundle of rights are complementary accounts. They are, in other words, different views of the same cathedral.

7 Note that exclusion is only half of the formal or structural story. As Penner explains, property rights are also "separable" or alienable in the sense that "only those 'things' in the world which are contingently associated with any particular owner may be objects of property": see Penner, above n 6, at 111.

8 Thomas W Merrill "Property and the Right to Exclude" (1998) 77 Neb L Rev 730 at 744.

9 Henry E Smith "Mind the Gap: The Indirect Relation between Ends and Means in American Property Law" (2009) 94 Cornell L Rev 959 at 963.

10 Henry E Smith "Property and Property Rules" (2004) 79 NYU L Rev 1719 at 1759.

11 Hanoch Dagan "Pluralism and Perfectionism in Private Law" (2012) 112 Colum L Rev 1409 at 1414-1415.

12 Henry E Smith "Mind the Gap: The Indirect Relation between Ends and Means in American Property Law", above $\mathrm{n} 9$, at 964 .

13 Penner, above $\mathrm{n} 6$, at 72. 
However, whilst the alienable right to exclude can explain the juridical form and legal structure of property rights, the exclusionary theory cannot explain the value of property rights. As Henry E Smith makes clear, "[e]xclusion is not the most important or 'core' value because it is not a value at all". ${ }^{14}$ Even for the most reclusive rights-holder, there is no value - in and of itself - in being able to exclude others from an object, asset, or resource. In order to understand the value of property rights in order to understand how property rights are a means of serving some kind of valuable ends - we need to consider the entitlements, activities and privileges that property rights enable and protect. As I will explain here, property rights serve valuable ends by allocating and protecting a bundle of rights: by enabling a right-holder to possess, consume, derive income from, control, manage, transfer, exchange (and so on) objects, assets and resources.

One way to understand the valuable ends of property is the satisfaction of the individual rightholder's preferences (or the exercise of his or her autonomy). The "one constant meaning" and "core purpose" of property, Gregory Alexander explains, has been "to define in material terms the legal and political sphere within which individuals are free to satisfy their own preferences, free from governmental coercion or other forms of external interference". ${ }^{15}$ Hence, it is our interest in the use and control of objects and resources - our interest in "purposefully dealing with things" 16 - that animates property rights with moral significance. Whilst the right to exclude formally protects this interest, our interest in purposefully dealing with things is elucidated through the various ways in which we use objects, assets and resources; through possessing, consuming, deriving income from, managing, transferring and so on. If property is a means of securing a person's use and control of an object, asset and resource, then the bundle theory of property is able to elucidate this valuable end, in a way that the exclusionary theory cannot.

Note that property, in the way just expressed, furthers a monistic value. That is, the valuable ends can be understood with sole reference to the right-holder's interest in "purposely dealing with things" (or, satisfying the right-holder's preferences, expressing the right-holder's will, or exercising the rightholder's autonomy). We could, in comparison, cast the net wider and consider the further ends that property law might seek to serve. On a value pluralistic view, the "main function of property is to structure social relations". ${ }^{17}$ This requires "a moral vision of what type of social relationships it seeks to foster". ${ }^{18}$

14 Henry E Smith "Property as the Law of Things" (2012) 125 Harv L Rev 1691 at 1705

15 Gregory S Alexander "Property as Propriety" (1998) 77 Neb L Rev 667 at 667.

16 Penner, above $\mathrm{n} 6$, at 71

17 Gregory S Alexander "Pluralism and Property" (2011) 80 Fordham L Rev 1017 at 1023.

18 At 1023 . 
On most pluralistic views, the moral ends of property are "a pluralistic set of liberal values: autonomy, utility, labour, personhood, community, and distributive justice". ${ }^{19}$ It then follows for Dagan that property law "tailors different configurations of entitlements to different property institutions". ${ }^{20}$ Through these different configurations, each property institution is "designed to match the specific balance between property values best suited to its characteristic social setting". ${ }^{21}$ Examples include: residential tenancy law (that protects aspects of personal identity or personhood); ${ }^{22}$ laws that govern relationship property division (that engage values of community sharing and distributive justice), ${ }^{23}$ and intellectual property (where there is a greater emphasis on utilitarian norms). ${ }^{24}$ These are all examples of a normative ballast that acts as a counterweight to autonomy or individual preference satisfaction of the property rights-holder.

Hence, there is an important distinction between valuable ends that property rights serve. Such ends can be understood as monistic (as serving one value) or pluralistic (as serving a range of values). Fortunately, with careful use of the language of "rights" and "law", we demarcate these monistic and pluralistic views. I will refer to "property rights" as serving the individual preference satisfaction whilst using "property law" to refer to the pluralistic task of "structuring the social relations" between individuals.

The key point which I wish to labour here is that this contrast between the valuable end(s) that property can serve is a contrast that is only visible through the lens of the bundle of rights theory of property: on the monistic account, by securing a bundle of privileges and entitlements for an individual rights-holder, property rights enable the rights-holder to satisfy his or her preferences; on the pluralistic account, in order to pursue a moral vision of the type of rights social relationships that ought to be fostered, property law can reallocate the bundle between potential rights-holders. Hence, "policy-motivated adjustments" to the bundle of rights "usually involve adding or subtracting sticks and reallocating them among concerned parties or to society". ${ }^{25}$ Once we view property law functionally, we can appreciate how the law might allocate and divide up the bundle of rights with a view of tailoring "different configurations of entitlements" that are "best suited to its characteristic social setting". ${ }^{26} \mathrm{I}$, therefore, suggest that, if the explanandum concerns the values that animate

19 Dagan, above n 11, at 1412-1413.

20 At $1412-1413$

21 At $1412-1413$.

22 At 1441; and Margaret Jane Radin "Property and Personhood" (1982) 34 Stan L Rev 957 at 992 and 1013.

23 Dagan, above n 11, at 1439.

24 At 1411

25 Henry E Smith "Property as the Law of Things", above n 14, at 1697.

26 Dagan, above n 11, at 1412-1413. 
property law with moral significance, then the bundle of rights theory provides the best available explanans.

Allow me to highlight three main analytical manoeuvres attempted here. First, I have suggested that there are two complementary explanations of property. The juridical form of property rights - its legal structure - can be adequately explained in terms of the right to exclude. The function of property rights - the social structure that it facilitates - can be explained in terms of a bundle of rights. Second, we can also identify two different accounts of the value, or moral ends, of property; as either only serving the autonomy or preferences of the rights-holder (value monism) or as serving a range of values, inclusive of individual preference satisfaction, but extending to include a range of social obligation norms (value pluralism). Third, I have also suggested here that our view of the contrast as to the valuable ends that a system of property rights serves is dependent upon adopting a functional lens, one that is concerned with how the law functions to structure the social relationships around objects, assets and resources.

\section{$B$ The Beneficial Interest}

In this Part, I will attempt the same three analytical manoeuvres whilst turning our attention to the beneficial interest under an express trust. Dissolving the tension between the alienable right to exclude and the bundle of rights in general property theory has been, in part, a dress rehearsal for considering the nature of the beneficial interest. Armed with the distinction between formal and functional views, we can attempt to diffuse the tension between the "obligational" and "proprietary" theories of the nature of the beneficial interest. I will then consider the moral ends that an express trust might be said to serve, and (at this stage of the article) merely isolate an implication that follows from the monistic and pluralistic views of the value(s) of an express trust.

Let us begin by viewing the express trust through the formal lens. If a property right represents the alienable right to exclude all others from an asset or resource, then when a settlor transfers an asset to the trustees of a trust, they are transferring the alienable right to exclude. That is, they are transferring rights that have a particular legal structure. The trustees, therefore, receive, and exercise, the alienable right to exclude all others from the trust asset. In receiving such rights under the terms of the trust, equity imposes obligations on the trustees: obligations that require the trustee to exercise their rights over the assets for the benefit of certain beneficiaries.

As we can see, when viewed through the formal lens, the trust represents an obligation imposed on the trustee to exercise their property right in a way specified. As Lionel Smith explains, "the trustee has rights in the object; that is, rights in the trust property" and the "beneficiary's rights are the converse of the obligations owed by the trustee to the beneficiary". ${ }^{27}$ It follows that the beneficiary does not obtain property rights under the trust. Rather, the beneficiary obtains a right that is

27 Lionel D Smith "Trust and Patrimony" (2008) 38 Revue Générale de Droit 379 at 392. 
exercisable against the trustees' property rights in the trust assets. It follows, for instance, that "if a third party wrongfully causes damage to the trust property", Smith identifies, "there is no claim by a beneficiary against the third party". ${ }^{28}$ The right of the beneficiary is not a right exercisable against an open set of people (a right in rem) that can be enforced by the beneficiary against a third party. More broadly, the rights of beneficiaries cannot be property rights - in the formal sense - since "the trust beneficiary has no equivalent direct right to exclude others from ... the trust asset". ${ }^{29}$ Viewed through a formal lens, the nature of the beneficial interest is, therefore, a non-proprietary interest. The beneficial interest is the corollary of the set of personal obligations imposed on the trustees as recipients of property under a trust.

In comparison, viewed functionally, the nature of the beneficial interest is a proprietary interest. When a settlor transfers an asset to the trustees of a trust, the trustees receive "powers of title". These "powers of title held by the trustee", ${ }^{30} \mathrm{JE}$ Penner explains, are the: ${ }^{31}$

... powers to transfer, confer rights in, or otherwise dispose of ... the right to possess tangibles or the right

(through legal action or equitable suit) to realise the value of intangibles.

The value of trust assets is (typically) realised through the acts of exchange, sale or reinvestment; it is not realised through the exercise of the rights "to immediate, exclusive possession". ${ }^{32}$ Although the right to exclude may protect the possession of the asset, the right to exclude is asserted by the trustees against interference as a way of protecting acts of exchange, sale and investment, thereby protecting the value of the trust asset. ${ }^{33}$ Whilst the beneficiaries under the trust do not have an interest in the rights that we associate with the formal structure of property rights, the beneficial interests lie "in their rights that the trustee exercise his [or her] power of title appropriately". ${ }^{34}$ The trustee must exercise his or her powers to exchange, sell or reinvest in a particular way in accordance with the beneficial interest. In this way, "the beneficiaries are the beneficial owners of the title to trust assets". 35

28 At 391

29 JE Penner "The (True) Nature of a Beneficiary's Equitable Proprietary Interest under a Trust" (2014) 27 CJLJ 473 at 476; and Ben McFarlane and Robert Stevens "The Nature of Equitable Property" (2010) 4 J Eq 1 at 34.

30 Penner "The (True) Nature of a Beneficiary's Equitable Proprietary Interest under a Trust", above n 29, at 487 (italics removed).

31 At 487 .

32 At 483

33 At 483

34 At 483 (italics removed).

35 At 487 . 
The beneficial interest is proprietary in the sense that the interest is located in the trust asset. Since the trustee exercises a set of powers in the trust asset, and since the rights of the beneficiary determine how those powers are exercised, the beneficiary has a legally protected interest in the trust asset. That is, the beneficiary has a legally protected interest in the bundle of powers that the trustee exercises; the beneficial interest is "in the trust asset". ${ }^{36}$ Whilst the powers and obligations of the trustees can multiply and fracture through complex trust arrangements, I suggest that they nonetheless crystallise around the "powers of title". That is, powers and duties, such as powers of appointment or duties to inform, are ultimately about the exchange, sale or reinvestment of the trust asset. It cannot be turtles all the way down. Rather, "the powers of title" provide the critical mass around which all trust powers and duties orbit.

Penner, therefore, encourages a shift in focus, away from possession and the trustees' alienable right to exclude and towards "the powers of title held by the trustee". ${ }^{37}$ This is acknowledged as a shift from form to function. ${ }^{38} \mathrm{We}$ are no longer explaining the beneficiaries' rights to trust property as a structure of rights that are exercisable against the alienable right to exclusion. ${ }^{39}$ Rather, we are now explaining the beneficiaries' rights function to require that the trustees exercise their powers of transfer, disposition and realisation of value, in some way that is beneficial to them; that is, the trust functions to allocate the bundle of rights into a particular configuration. Viewed functionally, the trust is a "configuration of rights": the trustees' powers to exchange, sell, reinvest the trust asset and the beneficiaries' rights to require the trustees to exercise these powers in a particular way.

I suggest that we again arrive at different explanans of different explananda. Where the phenomenon that calls for explanation is the juridical relationship between trustees, beneficiaries and third parties, then the obligational theory provides a sound explanation of that phenomenon. Where the phenomenon that calls for explanation is how property rights facilities the relationship between trustees, beneficiaries and the trust asset, then the proprietary view provides a sound explanation of that phenomenon.

Recall (from Part I(A)) that it is through the functional lens that we ought to consider the moral ends that the property institution serves. To understand the underlying point, rationale or purpose of the express trust, we need to approach the normative inquiry by considering the social structure that the express trust facilitates. If we understand the express trust in functional terms as a configuration

36 At 500 .

37 At 495 (italics removed).

38 At 484

39 Penner is nonetheless conceptually consistent with his above view that property rights are exclusive rights by emphasising that "the hallmark of a property right is not a right to exclusion, but a right to alienable exclusivity, which is the power to put another, a transferee into one's shoes as holder of an exclusive right": at 488-489 (italics removed). 
of rights, then we must consider the moral ends that this configuration of rights might then serve. The instinctive response is to say that the configuration of rights serves as the moral ends of the settlor's intention; more specifically, his or her autonomy or preference satisfaction that the settlor's intention represents. The reason why the law gives effect to a prescribed configuration of rights is because the settlor, as property rights-holder, intended such a configuration. If property rights define a "legal and political sphere within which individuals are free to satisfy their own preferences" 40 then giving effect to a settlor's intention is one instance of respecting this "protected sphere of indefinite and undefined activity, in which an owner may do anything with the things he owns". ${ }^{41}$ As we can readily appreciate, this is a value monistic account of the moral ends of the express trust. In the same way that we can view the moral ends of property rights as serving the preference satisfaction of the rights-holder, we can view the moral ends of the express trust as an instance of this monistic value.

A value monistic account of the express trust has an important implication that I wish to highlight here (and pick up again at Part II(B)). The implication is that, if the moral ends of trust law is settlor autonomy, then there are no limits to configuration of rights that the law has reason to enforce. If the settlor intends a particular configuration of rights - where trustees are immune from liability, where trustees are not held accountable, where trustees exercise unfettered discretion as to their own benefit under the trust - then it is consistent with the value of settlor autonomy for the law to give effect to that configuration.

The converse also holds. If we seek to prevent the settlor from creating "his [or her] local law for his [or her] autonomous trust", ${ }^{42}$ we need to identify a norm or something of value to counteract the settlor autonomy norm. We need to be able to show why "the law should prohibit settlors from creating trusts which differ from the trust concept as traditionally understood". ${ }^{43}$ Hence, understanding the moral ends of trust law as pluralistic, as engaging a range of values (and not just settlor autonomy), is necessary to explaining the trust as a particular configuration of rights (and not just the configuration that the settlor intended).

As we shall see, this is what the concept of the illusory trust attempts to do. It attempts to prescribe a limit to the particular configuration of rights that the law ought to give effect to, but without articulating the coherent pluralistic basis to the moral ends of the express trust. We will return to this contention in Part II(B). Before then, we need to consider the "bundle of rights" argument in the next Part. The bundle of rights argument relies upon the contention formulated here, concerning the two

40 Alexander "Property as Propriety", above n 15, at 667.

41 Penner, above n 6, at 72.

42 David Hayton "The Irreducible Core Content of Trusteeship" in AJ Oakley (ed) Trends in Contemporary Trust Law (Clarendon Press, Oxford, 1996) 47 at 48.

43 Patrick Parkinson "Review Essay: 'Trends in Contemporary Trust Law by A Oakley'" (1998) 20 Syd LR 348 at 353 . 
complementary explanations of the beneficial interest. That is, where the phenomenon that calls for explanation is the structure of juridical relationships in the express trust, then the beneficial interest is the corollary of personal obligations owed to the beneficiaries by the trustees. Where the phenomenon that calls for explanation is structure of social relationships with regard to the trust property, then the beneficial interest represents the set of rights that have been configured to be exercisable by the beneficiaries.

\section{PART TWO}

\section{A The Bundle of Rights}

Let us now overlay our functional and formal theories. In Part I(A), I suggested that "property" can be understood formally as the right to exclude or functionally as a bundle of rights. In Part I(B), I suggested that the beneficial interest can be understood formally as the corollary of the personal obligations owed by the trustee to the beneficiary, or functionally as the ability to determine how the "powers of title" are exercised. Now, the formal relationship is the juridical relationship. It explains the legal form or structure of the legal relationship between trustees and beneficiaries with regard to the trust property. As far as the courts may be concerned, the juridical relationship ought to be the focus. There seems to be no need for a court to look beyond justiciable rights and duties and consider how the law functions to shape the social relationship between people and property.

Legislation, however, can necessitate a shift in focus from the formal to the functional. For instance, legislation may take aim at the assets held by debtors in light of a creditor's claim for restitution or corrective justice, ${ }^{44}$ alter assets held by parties to property settlement proceedings in recognition of non-financial contributions to the marriage or partnership ${ }^{45}$ seek to assess the financial resources of individual when evaluating his or her access to legal aid, ${ }^{46}$ or assess financial resources of an individual when evaluating his or her obligation to contribute to taxation. ${ }^{47}$ The difficulty is that, if these legislative provisions concern "property" in the formal sense, then a beneficiary under a general discretionary trust has no proprietary interest in the trust property. Recall that, under the formal view, the beneficial interest is obligational and not proprietary. A beneficiary under a general discretionary trust has no legal or equitable interest in the trust property, but a mere expectation that the trustees' discretion may be exercised to his or her benefit. ${ }^{48}$ If we sustain the formal view, it then

44 Property Law Act 2007, s 345.

45 Property (Relationships) Act 1976, ss 44, 44B and 44C; and Family Proceedings Act 1980, s 182.

46 Legal Services Act 2000, s 8 and sch 1 (cl 4 and 5); and Legal Services Regulations 2006, reg 8(4).

47 Income Tax Act 2007, s BG 1.

48 Hunt v Muollo [2003] 2 NZLR 322 (CA) at [11]; and Gartside v Inland Revenue Commissioners [1968] AC 553 (HL) at 607 per Lord Reid and 615 per Lord Wilberforce. 
follows that the legislative provisions that aim to reallocate and redistribute "property" cannot capture the beneficial interest under a general discretionary trust.

Sustaining the formal view in this context is a mistake. When a legislative provision aims to reallocate "property", it is attempting to limit or redistribute a privilege or entitlement in an object, asset or resource. That is, the legislative provision is seeking to make "policy-motivated adjustments" to the bundle of rights by "adding or subtracting sticks and reallocating them among concerned parties or to society". ${ }^{49}$ Legislative intervention with regards to "property" is intervention that is concerned with the social structure that property law facilitates.

Take, for example, the Property (Relationships) Act 1976. It is clear that the Act is concerned with the social structure that property facilitates. Its stated purpose is to: ${ }^{50}$

(a) to reform the law relating to the property of married couples and civil union couples, and of couples who live together in a de facto relationship;

(b) to recognise the equal contribution of both spouses to the marriage partnership, or civil union partners to the civil union, and of de facto partners to the de facto relationship partner; and

(c) to provide for a just division of the relationship property between the spouses or partners when their relationship ends ...

With regards to marriage partnerships, civil unions and de facto partnerships, the purpose of the Act is to restructure the relationship of the two people in the partnership and the property that each of them possessed, used, controlled, derived income from and so on. Relationship property legislation, such as this, promotes values of community sharing and distributive justice with "a moral vision of what type of social relationships it seeks to foster" 51 by affirming that "men and women have equal status", that "all forms of contribution to ... [a] partnership ... are treated as equal", and that "a just division of relationship property has regard to the economic advantages or disadvantages to the ... partners arising" from the partnership. ${ }^{52}$

This is Bill Atkin's contention. As he explains: ${ }^{53}$

The Property (Relationships) Act 1976 (PRA) is ostensibly about property but its policy goals are about people and the fair division of the property that was central to the couple's life.

Atkin here is restricting himself to a formalistic understanding of property. The Property (Relationships) Act is still "about property", just property in a functional sense. The suggestion here

49 Henry E Smith "Property as the Law of Things", above n 14, at 1697.

50 Property (Relationships) Act, s 1M.

51 Alexander "Pluralism and Property", above n 17, at 1023.

52 Property (Relationships) Act, s $1 \mathrm{~N}$.

53 Bill Atkin "What Kind of Property is 'Relationship Property'?" (2016) 47 VUWLR 345 at 345. 
is that "property", under the Act, should not be understood formally "by reference to the powers and rights it gives the owner", but rather functionally "by reference to the impacts of the exercise of this power on others and the shape and character of the social relationships engendered by those rights and powers". 54

It should have come as no surprise to the academic and legal community that "property" under the Property (Relationships) Act has been interpreted functionally and not formally. For instance, in Walker $v$ Walker, the Court of Appeal viewed a debt that was owed to the husband by a discretionary family trust as "relationship property". ${ }^{55}$ Since the husband had "control" over the corporate trustee company, the debt was attached to a "package of assets" that were exercised by the husband. ${ }^{56}$ This "package", according to the Court of Appeal, "should have been valued on an assumption that they were for sale together" when "maximising the value of the relationship property". ${ }^{57}$ If we accept that "property" for the purposes of the Act ought to be understood with reference to the "the shape and character of the social relationships engendered by" rights and powers, ${ }^{58}$ then a court ought to view the trust in functional terms. By doing so, the power to appoint and remove directors of a trustee company, and the power appoint and remove trustees of the trust, can contribute to the package of assets that is classified as "property" for the purposes of the Act.

This approach to "property" under the Property (Relationships) Act was subsequently followed by Harrison $v$ Harrison.${ }^{59}$ Here, a husband and wife settled a family trust with a trust company as the trustee. The High Court held that since the trustee company was under the control of the parties, the "substantial effect of the arrangement" 60 was that the parties controlled the trust ${ }^{61}$ and "the legal and equitable estates unite in the husband and wife."62 On an application to the Court of Appeal, rather than viewing the trust as ineffective, the Court observed that: ${ }^{63}$

54 Joseph William Singer "Democratic Estates: Property Law in a Free and Democratic Society" (2009) 94 Cornell L Rev 1009 at 1047.

55 Walker $v$ Walker [2007] NZCA 30, [2007] NZFLR 772; and Frances Gush "The 'bundle of rights' Unravelling trust principles" (2012) 7 NZFLJ 157 at 160.

56 Walker, above n 55, at [48].

57 At $[60]$.

58 Singer, above n 54, at 1047

59 Harrison v Harrison (2008) 27 FRNZ 202 (HC) [Harrison (HC)]; Harrison v Harrison [2009] NZCA 68, [2009] NZFLR 687 [Harrison (CA)]; and Gush, above n 55, at 160.

60 Harrison (HC), above n 59, at [22].

61 At [25].

62 At [26].

63 Harrison (CA), above n 59, at [10]. 
... there was a bundle of rights associated with their positions as discretionary beneficiaries under the [trust company], and as the joint holders of the power of appointment of the [trust company] trustees.

The same approach was adopted by the Supreme Court in Clayton v Clayton. ${ }^{64}$ In this case, the sole trustee was also a "discretionary beneficiary" and exercised broad powers of discretionary distribution of income and capital, amendment, self-benefit, appointment and removal of trustees and beneficiaries. Rather than finding that the trust was ineffective (or illusory), the Supreme Court held that the sole trustee's ability to exercise "the [trust] powers in his own favour to the detriment of the Final Beneficiaries" in a manner that is "unrestrained by fiduciary obligations" meant that these powers amount to "property" under the Property (Relationships) Act. ${ }^{65}$ The legislative intervention required a shift in focus from form to function, and once viewed functionally, the sole trustee (and "discretionary beneficiary") powers "to transfer, confer rights in, or otherwise dispose of ... the right to possess tangibles" were a proprietary interest that ought to be reallocated under the Act. ${ }^{66}$

Hence, we can begin to see how the "bundle of rights" theory takes shape. It represents an interpretative approach to legislation that seeks to reallocate or redistribute "property". The theory encourages a functional approach to the meaning of "property", recognising that law reform is often concerned with the structure of the social relationships that property institutions facilitate, rather that the juridical structure itself. More broadly, this functional approach is required regardless of whether the "property" in question concerns a financial debt to a creditor underpinned by corrective justice norms, the social debt to a former husband or wife underlined by distributive justice norms or the social obligation to contribute to public revenue gathering.

Let me, therefore, articulate the coherent basis to "the bundle of rights" approach. The social institution of property engages a plurality of values. Legislation may seek to reallocate or redistribute "property" in order to pursue a moral vision of the type of social relationships that ought to be fostered. ${ }^{67}$ It does so by making "policy-motivated adjustments" to the sticks in the bundle of rights. ${ }^{68}$ When applying allocative or redistributive legislative provisions, courts ought to adopt a functionalist interpretation of the term "property". Where the asset, object or resource in question is subject to a general discretionary trust, a functional interpretation of "property" is inclusive of a beneficiary's ability to require that the trustees exercise their powers of transfer, disposition and realisation of value in favour of him or her. Such an approach is inconsistent with the juridical principles of trust law, and

64 Clayton v Clayton [2016] NZSC 29, [2016] NZFLR 230.

65 At [58].

66 Penner "The (True) Nature of a Beneficiary's Equitable Proprietary Interest under a Trust", above n 29, at 487.

67 Alexander "Pluralism and Property", above n 17, at 1023.

68 Henry E Smith "Property as the Law of Things", above n 14, at 1697. 
that is the entire point. Legislative reform has never been beholden to mantra of the Chancery. Nor should it be.

Finally, the reason why the bundle of rights theory is restricted to legislative intervention is because the statutory provisions provide both the catalyst for the shift from form to function and the injection of a plurality of values. It is legislation that can provide additional protection for residential tenants and creditors, govern relationship property division and intellectual property rights, preserve historical features and access to legal aid, manage environmental resources, gather public revenue and so on. It is legislation that confronts the task of arbitrating between the individual preference satisfaction norms and social obligation norms. This requires balancing what is good for a person, what that person values, and what he or she rationally prefers, ${ }^{69}$ against the obligations on the same person "to provide to the society of which the individual is a member those benefits that the society reasonably regards as necessary". ${ }^{70}$ What is much less clear is whether this value pluralistic task can be achieved independent of statutory intervention. We can now turn to consider this final question.

\section{B The Illusory Trust}

Recall the implication that I drew at the end of Part I(B): if the moral ends of trust law is settlor autonomy, then there are no limits to the configuration of powers that the law has reason to give effect to. Equally, if we seek to provide a limit to the settlor exercising his or her autonomy by requiring particular beneficiaries' rights or trustees' obligations, we need to identify something of value to counteract the settlor autonomy norm. As I will explain here, those who seek to identify an internal limit to the concept of a trust, where the trust becomes "illusory" if it exceeds the limit, must confront the second formulation of the implication. Unlike the bundle of rights argument, which is able to draw upon a plurality of values by virtue of statutory provisions that introduced values beyond the value of settlor autonomy, the concept of the illusory trust relies upon the idea that trust law itself serves a plurality of values.

In terms of there being a limit to the concept of the trust, we are concerned here with "arrangements that were subjectively intended to create an express trust, but are found not to do so because of the control formally provided to the trustee or settlor". ${ }^{71}$ That even when a settlor intended a particular configuration of powers, it does not conform to the standard "package of legal incidents" 72

69 Gregory S Alexander "Property's Ends: The Publicness of Private Law Values" (2014) 99 Iowa L Rev 1257 at 1263 .

70 Gregory S Alexander "The Social-obligation Norm in American Property Law" (2009) 94 Cornell L Rev 745 at 774 .

71 Mark Bennett "Competing Views on Illusory Trusts: The Clayton v Clayton litigation in its wider context" (2017) $11 \mathrm{~J} \mathrm{Eq} 48$ at 54.

72 Lionel Smith "Constructive Trusts and Constructive Trustees" (1999) 58 CLJ 294 at 299. 
or "package of constituent elements"73 that the law requires "when parties choose to use the trust institution to order their affairs". ${ }^{74}$ At which point, the elasticity of the trust concept "is stretched to breaking point" ${ }^{75}$ the "trust for beneficiaries then becomes a bare resulting trust for the settlor" ${ }^{76}$ and the "apparent trust created by the settlor would be unreal". ${ }^{77}$ There must be, in other words, some way of delineating the concept of the trust to give effect to the idea that a trustee holds property as a trustee, and not, as a bare property rights-holder. ${ }^{78}$

Formally, of course, the trustee is the property rights-holder. The trustee exercises the right to exclude - exercises the "rights in the trust property" - that are nonetheless rights subject to "obligations owed by the trustee to the beneficiary". ${ }^{79}$ It then follows that, provided the trustee is under obligations that are owed to the beneficiaries, the trustee is not a bare property rights-holder. The juridical form of the trust, therefore, requires a set of obligations that are imposed on the trustee(s) and owed to the beneficiaries, in order to sustain the concept of the trust. For instance, one way to formally delineate the concept of the trust is to focus on how the obligations imposed on the trustee creates a "relationship of accountability between trustee and beneficiary. ${ }^{80}$ It then follows that "if the settlor does not confer upon so-called 'beneficiaries' any formal rights to make the trustee account to them", 81 the ostensible trust has reached beyond the formal limits of the trust.

Note that it might be tempting to add to the conceptual account of the trust the observation that such obligations are fiduciary obligations. However, the fiduciary dimension to a fiduciary obligation concerns a particular manner in which the obligation ought to be performed; it ought to be performed with loyalty, faithfulness or some other justiciable motive. ${ }^{82}$ The manner in which an obligation is required to be performed is logically subsequent to the content of the obligation itself (ie the actions that are required to be performed). The idea that there is a limit to the concept of the trust is constructed

73 Richard Nolan "Equitable Property (2006) 122 LQR 232 at 254.

74 Lionel Smith "Constructive Trusts and Constructive Trustees", above n 72, at 299.

75 David Hayton "Anglo-Trust, Euro-Trusts and Caribbo-Trusts: Whither Trusts" in Modern International Developments in Trust Law (Kluwer Law International, Alphen aan den Rijn (Netherlands), 1999) 1 at 5.

76 At 5 .

77 David Fox "Non-Excludable Trustee Duties" (2011) 17 Trusts \& Trustees 17 at 17.

78 James Penner "Exemptions" in Peter Birks and Arianna Pretto (eds) Breach of Trust (Hart Publishing, Oxford, 2002) 241 at 241

79 Lionel D Smith "Trust and Patrimony", above n 27, at 392.

80 Hayton, above n 42, at 49-50.

81 David Hayton "Exploiting the Inherent Flexibility of Trusts" in Modern International Developments in Trust Law (Kluwer Law International, The Hague, 1999) 335 at 319-320.

82 Lionel Smith "The Motive, Not the Deed" in Joshua Getzler (ed) Rationalizing Property, Equity and Trusts: Essays in Honour of Edward Burn (LexisNexis, London, 2003) 53 at 67. 
by the imposition of obligations of particular content (that may subsequently require a particular manner or motive of performance).

Recent commentary has sought to further delineate the concept of the illusory trust in the wake of the Supreme Court's decision in Clayton v Clayton. Mark Bennett provides an excellent account of these different formulations. ${ }^{83}$ Although the Supreme Court did not rely on the illusory trust concept, the Court nonetheless acknowledged that the retention of broad powers by the settlor "may bring into question whether the irreducible core of Trustee obligations" exists. ${ }^{84}$ These recent attempts to further delineate the concept of the illusory trust rely upon a shift from form to function. That is, they require the courts to look beyond the juridical relationship between trustee and beneficiary into the structure of social relations that the trust is giving effect to with regards to the trust property. As I will explain, this functionalist turn requires an explanation of why courts should look beyond the juridical form, and more importantly, this functionalist turn necessitates an explanation of the values that inform the functional limits of the concept of the trust.

One way to extend the concept of the illusory trust is to expand upon the relationship of accountability and require "meaningful accountability". ${ }^{85}$ The suggestion here is that even where there are duties to account imposed on the trustees, where the substance of the trust structure precludes trustees being held accountable by the beneficiaries, the settlor intention to create a trust can be called into doubt. Such an approach requires the courts to look at "[t]he reality of how the trust was structured and what the various powers conferred on [the trustee are]", ${ }^{86}$ and to depart from a "formulaic analysis" of trust intention to take "take account of substance and conduct". ${ }^{87}$ This "inquiry as to substance" 88 is concerned with how beneficiaries' rights function to require that trustees exercise their powers of transfer, disposition and realisation of value in a particular way. It is, in other words, concerned with how the powers under the trust are functionally configured and exercised.

Another way to expand the concept of the illusory trust is to view a trustee's ability to benefit from the trust (or benefit to a particular degree) to be inconsistent with the role of a trustee. ${ }^{89}$ Tobias Barkley, for instance, posits that "the purpose of trusts ... is to provide legal recognition for an important category of social relationship" that is "created when one person promises to use property

83 Bennett, above n 71, at 48-79.

84 Clayton, above n 64, at [124].

85 Jessica Palmer and Nicola Peart "Clayton v Clayton: a step too far?" (2015) 8 NZFLJ 114 at 118 (emphasis added).

86 At 118 .

87 At 118

88 At 118

89 Bennett, above n 71, at 65 . 
or assets they own, receive or have control over for the benefit of someone or something other than him or herself". ${ }^{90}$ Note that Barkley then attempts to justify this claim on the basis that it is "consistent with a long line of judicial statements on the nature of trusts". ${ }^{91}$ Barkley's claim is, nonetheless, a functional claim about how trust law facilities the structure of social relations with people and property, specifically with reference to the entitlements of use, transfer, control and income.

A third way is to look "beyond the strict legal form of the arrangement to examine whether in substance or 'reality' the powers provided in the trust deed" enable the settlor or trustee to "have the benefit of the property". ${ }^{92}$ As Bennett explains, according to this "reality of control view", the trust will be illusory where they settlor retains powers under the trust to "give binding directions for investment", to "give or withhold consent for the exercise of the trustee's powers", to "replace trustees or protectors, to direct the distribution of trust assets contrary to the terms of the trust deed", or to "act as a director of a company whose shares are owned by the trust". ${ }^{93}$ This view is clearly a functional view of the limits of the trust; there are certain powers under the trust that crystallise around the "powers of title" and cannot be exercised by the settlor despite the settlor's intention to retain such powers.

More broadly, all three views briefly considered here require a functional shift. That is, all three views seek to look beyond the juridical relationship between trustee and beneficiary to assess whether the trust has the effect of creating a structure of social relations whereby the trustees or settlor exercise the powers of transfer, disposition and realisation of value in a way that is somehow inconsistent with the concept of the trust.

Consider now the contrast between the bundle of rights argument and the concept of the illusory trust. There are two points of contrast. Unlike the bundle of rights argument that is predicated on statutory intervention, there appears to be no catalyst for the shift from viewing the trust in terms of juridical relationships, to viewing the trust in terms of how the powers of transfer, disposition and realisation of value are exercised "in substance" or "in reality". Absent statutory intervention, the juridical principles of equity will apply. ${ }^{94}$

Moreover, unlike the bundle of rights argument that is animated by the pluralistic rationale behind the statutory intervention, it remains unarticulated what value is being invoked to act as a ballast or

90 Tobias J Barkley "The content of the trust: what must a trustee be obliged to do with the property?" (2013) 19 Trusts \& Trustees 452 at 460 .

91 At 461 .

92 Bennett, above $\mathrm{n} 71$, at 70 (footnotes omitted).

93 At 71 .

94 See Nation v Nation [2005] 3 NZLR 46 (CA) at [147]-[148]; and Financial Markets Authority v Hotchin [2011] 3 NZLR 469 (HC) at [130]-[133]. 
counterweight against respect for settlor autonomy. We need this "ballast value" to furnish the law with reasons not to give effect to the configuration of rights, powers, and privileges that the settlor intended. Otherwise, absent a ballast value, we have to accept the singular moral ends of trust law as giving effect to settlor autonomy. And by accepting value monism, we arrive at a "strong version" of a "freedom of trust" principle, whereby: ${ }^{95}$

... so long as the legal arrangement of rights and duties voluntarily undertaken by the parties has some

kind of workable legal effect, the law should give effect to it; it is not the role of the law to require parties

to a legal arrangement to accept a standard "package" of terms ...

Relying upon iterations of "the essential historical character of the trust" 96 does not explain why "the law should prohibit [a] settlor from creating trusts which differ from the trust concept as traditionally understood". 97 Even identifying "axiomatic principles", "a long line of judicial statements on the nature of trusts",98 or repeating the "recurrent themes of accountability and enforceability" in the trust law, ${ }^{99}$ does not explain the way in which accountability, enforceability, or any other "category of social relationship", 100 are ballast values internal to trust law.

In the same way that "[e]xclusion is ... not a value at all",101 "meaningful" accountability, a sufficient degree of selflessness or limited control are not valuable in and of themselves. In order for the concept of the illusory trust to have a coherent basis, we need an understanding of some moral end, that is being served by requiring "meaningful" accountability, limiting self-benefit, or limiting effective control, that (in some circumstances at least) is more valuable than settlor autonomy. Moreover, if we are to identify what form of accountability is not "meaningful" accountability, what degree of self-benefit is too beneficial, or what degree of control is "effective" control, we need to understand the value or norm that animates this limit to the settlor's intention (and the autonomy or preference satisfaction that the intention represents). Rather than there being "[n]o coherent basis for the bundle of rights" argument, ${ }^{102}$ there has instead been no coherent basis for the concept of the illusory trust articulated to date.

95 Penner "Exemptions", above n 78, at 250.

96 Lionel Smith "Access to Trust Information: Schmidt v Rosewood Trust Ltd" (2003) 23 Estates, Trusts \& Pensions Journal 1 at 8.

97 Parkinson, above $\mathrm{n}$ 43, at 353.

98 Barkley, above n 90, at 461.

99 Daniel Clarry "The Irreducible Core of a Guernsey Trust: The Offshore Trustee en bon père de famille" (2014) 17 JGLR 5 at [46].

100 Barkley, above n 90, at 460 .

101 Henry E Smith "Property as the Law of Things", above n 14, at 1705.

102 Law Commission, above n 1, at 46. 
This conclusion should not be interpreted as a defence of the freedom of trust principle. Far from it. This article seeks to better identify the enemy in order to better combat it. Property rights are value monistic, and it is because there are values beyond individual preference satisfaction that we "use a combination of common law, statutes, and social custom to define the boundaries of allowable packages of property rights". ${ }^{103}$ Trust law, I have suggested, is also value monistic. Seeking to find normative limits to the concept of a trust from within trust law is akin to staging an intervention for an addict by inviting only drug dealers. Rather, we need to look outside trust law and apply legal tools that have a value pluralistic basis. One answer, I have suggested, lies with the bundle of rights argument. This argument requires a functionalist interpretation of legislative provisions that seek to reallocate and redistribute "property", whether the legislation concerns creditors, relationship property, legal aid, taxation, or any other instance where a social obligation outweighs individual preference satisfaction.

\section{CONCLUSION}

When we ask, "is this power property?" or "what is the nature of the beneficial interest?", we do not isolate the explanandum that requires explanation. We can ask, with more clarity, whether a right is a property right and whether a right is governed by property law. We can also ask, with more clarity, what the juridical nature of the beneficial interest is and what the functional nature of the beneficial interest is. Once we isolate these distinct explananda, we can then view the ostensibly competing explanans as different explanans for different explananda.

It then becomes a question of which lens we ought to adopt. Adopting a formal lens helps us understand the juridical relationship between rights-holders and duty-bearers. Adopting a functional lens helps us understand the social relationship between people and property that the law facilitates. It is this functional lens that enables us to see a plurality of values that property institutions can serve. The bundle of rights argument is an argument in favour of adopting the functional lens. Where legislation seeks to make adjustments and reallocations to the sticks in the bundle of rights in light of a plurality of values, what amounts to a "property" interest ought to be interpreted functionally. The recent attempts to delineate the concept of the illusory trust also represent a functional shift, in an attempt to view the "substance" or reality" of the trust. However, without identifying a plurality of values that trust law itself seeks to serve, the limit to the concept of the trust will remain illusory.

103 Singer, above n 54, at 1052. 